\title{
Investment maintenance of development of agrarian enterprises of Zakarpattia
}

\author{
H. Spaskyi, \\ Doctor of Science Economics \\ M. Rusnak
}

Station Zakarpatian State Agricultural Experimental

The purpose. The great value of investments into agrarian enterprises of Zakarpattia is proved, and also the solution of problems concerning investment maintenance is offered. Methods. Monographic, calculation, mathematical-and-statistical. Results. Essential increase of investments in agriculture did not contribute to conforming growth of efficiency indices of the work of agrarian enterprises. Volumes of production of agricultural produce have grown in general in 1,3 times. The most effective in agrarian sector was use of work, but rates of payment outrun rates of increase of productivity of work in agricultural enterprises. Conclusions. Development of agriculture in strategic prospect demands substantial improvement of its investment maintenance in agrarian enterprises and farms.

Key words: investment maintenance, agrarian enterprise, agriculture, investment system.

Problem setting. Activation of investments activity in agriculture of Transcarpathia contributes to the increase of volumes of the agrarian production, increase of profitability, widening of the productive activity, creation of additional working places in the rural areas and on the industrial enterprises, increase of the level of satisfying the consumer needs of population and improving the development of the social sphere of the village.

It had been proved by the many years' experience that the increase of the level of investment provision of the agrarian enterprises contributes to the creation of volumes of production, increase of the branch's efficiency (first of all - profitability and productivity of labor), strengthening of the food security, and also solving the social problems of the region's rural area.

Analysis of the latest investigations and publications. Theoretical and applied aspects as to the problem of involving the investments into the agrarian enterprises of the regions had been researched in the scientific works of such home and foreign investigators, as Balyan A.V.[2], Gavryliyk O.V. LupenkoY.O.[4], Hytman L.J., Jonka M.D. (3], Kvasha S.M.[6], Kozhemyakina M.Y.[7], Malika M.J. [9], Sabluk P.T.[1], Mc Connel C.R.., Brue S.L.[5], Peresada A.A.[10], Shkuratov O.I.[8]. And others. However, there is a set of questions that remain a constant object of investigations, besides, on the possibility of activation the involvement of the investments into the agrarian enterprises of Transcarpathia.

Investment, as a separate direction in the economic science, appeared in the first half of the XX c. The beginning of its development is considered to be the 50-ties, when Harry Markovitz's article "The choice of the brief case" had been published. [13]. Having grounded the methodology of making decisions on the financial investments, he had also given the corresponding financial instruments.

O.D. Vovchak under the term investments understands the expenditures on the creation, widening and technical re-equipment of capital, meaning the today's spending, the aim of which is to obtain the future profits. [3].

L.J.Hitman and M.D.Jonk state, that the investments provide the mechanism, necessary for financing the increase and development of economics and its separate branches. Simply saying, investments - are any instrument, in which the money can be put, considering preserving them or contributing their value and providing the positive amount of income. [5]. 
The most rational is the definition of the authors of "Economics". Thus, according to K. McConnel and S. Brue, investments are the expenditures on the building of the new factories, on machine tools and equipment with the long term of use, spending on production and accumulation of means of production, increase of material resources, expense on the education improving, on increase of mobility of the labor power. [6].

Aim of the article - grounding the important meaning of investments for the agrarian enterprises of Transcarpathia. The solutions of the problems as to the investments provision had also been proposed.

Basic results of investments' exposition. The most important component of changes, which provides the fast reaction of agrarian enterprises on the influence of the factors of inner and outer environment is effective investment provision. Re establishment of the investor's trust, skillful use of various investment sources, improvement of the investment climate, preserving their own and growing the innovative potential of development and investment attractiveness - are basic directions on which the attention should be concentrated.

In the modern conditions a great meaning has the division of the investments according to the types of economiic activity. Statistics data wittness that there is a process of growing the investments, which are directed into the industry, while a total part of investments into agriculture had increased during the period under analysis, from $1,2 \%$ to $1,7 \%$, and into industry had increased correspondingly from 16,0 to $22,8 \%$ (table. 1).

1. Investments into the basic capital according to the types of economic activity of Transcarpathia

\begin{tabular}{|c|c|c|c|c|c|c|}
\hline \multirow[t]{3}{*}{ Year } & \multicolumn{6}{|c|}{ Investments in the basic capital in the comparative prices } \\
\hline & \multicolumn{2}{|c|}{ In agriculture } & \multicolumn{2}{|l|}{ In industry } & \multicolumn{2}{|c|}{ Total } \\
\hline & MIn.hrn & $\%$ & mln. hrn & $\%$ & MIn. Hrn & $\%$ \\
\hline 2001 & 6,2 & 1,2 & 82,9 & 16,0 & 519,2 & 100,0 \\
\hline 2002 & 6,4 & 1,1 & 80,4 & 13,9 & 576,6 & 100,0 \\
\hline 2003 & 7,4 & 0,8 & 114,9 & 11,9 & 966,8 & 100,0 \\
\hline 2004 & 8,0 & 0,6 & 311,3 & 22,6 & 1374,3 & 100,0 \\
\hline 2005 & 18,1 & 1,6 & 295,7 & 26,5 & 1114,6 & 100,0 \\
\hline 2006 & 24,2 & 1,3 & 565,5 & 30,6 & 1844,6 & 100,0 \\
\hline 2007 & 48,5 & 1,4 & 791,4 & 23,2 & 3409,1 & 100,0 \\
\hline 2008 & 39,4 & 1,2 & 864,2 & 26,1 & 3303,5 & 100,0 \\
\hline 2009 & 57,1 & 3,0 & 608,9 & 31,8 & 1914,7 & 100,0 \\
\hline 2010 & 46,7 & 2,1 & 443,3 & 20,1 & 2205,4 & 100,0 \\
\hline 2011 & 44,7 & 1,8 & 556,6 & 18,2 & 2455,5 & 100,0 \\
\hline 2012 & 45,8 & 1,7 & 660,6 & 24,1 & 2736,1 & 100,0 \\
\hline 2013 & 46,7 & 1,8 & $\begin{array}{l}728,2 \\
\end{array}$ & 27,5 & 2645,8 & 100,0 \\
\hline 2014 & 41,2 & 1,6 & 747,0 & 28,3 & 2638,7 & 100,0 \\
\hline 2015 & 65,5 & 1,7 & 859,6 & 22,8 & 3778,4 & 100,0 \\
\hline
\end{tabular}

Source: Statistic yearly annual of Transcarpathia over 2015. Statistics headquarters in Transcarpathia. Uzhgorod 2016y.[6]

As we see from the given in table 1 data, the volumes of investments into the basic capital of agriculture had increased in 6,6 times, industry - 10,4 times already. A strictly defined tendency is being observed as to the increase of the part of investments, directed into the industrial production, while the increase into agriculture had taken slower tempo - investments into the basic capital. Taking into consideration the fact, that in 2015 in the structure of gross extra value the industry makes up $16,2 \%$, and industry $14,8 \%$, than the proportions of division the investments between these types of economic activity is not fair. The analysis of dynamics of the volume of resources, which are directed on the strengthening of the material-technical basis of agriculture of the region and indicators of its activity, especially of the volumes of agricultural goods production, labor productivity, efficiency of land use, level of average salary had been given in (table 2). 


\section{Figures of agriculture activity and volumes of investments of Transcarpathia}

\begin{tabular}{|c|c|c|c|c|c|c|c|c|c|c|c|c|c|}
\hline Figure & 2001 & 2003 & 2004 & 2006 & 2008 & 2009 & 2010 & 2011 & 2012 & 2013 & 2014 & 2015 & $\begin{array}{l}2015 \text { in } \\
\% \quad \text { to } \\
2001\end{array}$ \\
\hline 1 & 2 & 3 & 4 & 5 & 6 & 7 & 8 & 9 & 10 & 11 & 12 & 13 & 14 \\
\hline $\begin{array}{l}\text { Investments into the basic } \\
\text { capital of agriculture, game } \\
\text { management, and } \\
\text { providing the } \\
\text { corresponding services In } \\
\text { corresponding prices - } \\
\text { together, mln.hrn }\end{array}$ & 6,2 & 7,4 & 8,0 & 24,2 & 39,4 & 57,1 & 46,7 & 44,7 & 45,8 & 58,1 & 41,2 & 65,5 & $\ln 6,6$ \\
\hline $\begin{array}{l}\text { Per 1ha of agricultural } \\
\text { lands, hrn }\end{array}$ & 54,6 & 82,7 & 139,5 & & & & 103,3 & & & 128,7 & 91,4 & 145,2 & \\
\hline $\begin{array}{l}\text { Direct foreign investments } \\
\text { in agriculture, mln.dollars, } \\
\text { USA }\end{array}$ & 1,6 & 4,0 & 3,0 & 1,5 & 1,6 & 1,7 & 1,9 & 2,7 & 4,9 & 3,1 & 2,9 & 2,6 & $\begin{array}{l}\text { In } 1,6 \\
\text { times }\end{array}$ \\
\hline 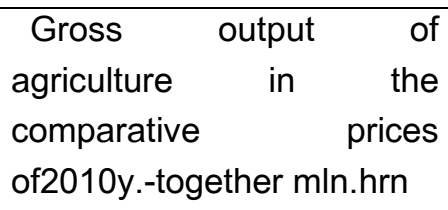 & 3272,4 & 3334,4 & 3552,2 & 3739,3 & 3766,7 & 3788,9 & 3838,3 & 3998,9 & 4207,3 & 4312,9 & 4308,3 & 4095,9 & $\begin{array}{ll}\text { In } & 1,25 \\
p & \end{array}$ \\
\hline 1 & 2 & 3 & 4 & 5 & 6 & 7 & 8 & 9 & 10 & 11 & 12 & 13 & 14 \\
\hline $\begin{array}{l}\text { per } 100 \text { ha of agricultural } \\
\text { lands, th hrn }\end{array}$ & ,3 & 0 & ,8 & 1 &, 5 & ,9 & 6 & ,9 & & 955,6 & 955,5 & 908,1 & $\begin{array}{l}1,6 \\
\text { times }\end{array}$ \\
\hline $\begin{array}{l}\text { Labor productivity in } \\
\text { agricultural enterprises } \mathrm{hrn}\end{array}$ & 15845 & 17631 & 28976 & 39386 & 45355 & 47896 & 51245 & 55456 & 56856 & 57443 & 57889 & 59334 & $\ln 3,7$ \\
\hline $\begin{array}{l}\text { Monthly nominal payment } \\
\text { of the hired workers in } \\
\text { agriculture, hrn }\end{array}$ & 311 & 462 & 590 & 1041 & 1552 & 1785 & 1846 & 2105 & 2351 & 2553 & 2744 & 2966 & 9,5 \\
\hline
\end{tabular}

Source: Statistic yearly annual of Transcarpathia over 2015. Statistics headquarters in Transcarpathia. Uzhgorod 2016y.[6] 
As it is seen from the table, the investments into the basic capital in general during the period of investigation had increased in 6,6 times, (the average yearly tempo of increment made up 45,6\%), in reliance on the unit of area - in 6,7 times (yearly average growth tempo-55,6\%). Whereas the considerable tempo of the given indicator increase, the value of investments on 599,3 hrn. on 1 ha of agricultural lands, by no means it can't be considered to be enough for the satisfaction of the needs of agricultural enterprises.

The investigations confirm that the essential increase of investments into agriculture didn't lead to the corresponding increase of the indicators of the efficiency of activity of the agrarian enterprises. The volumes of agrarian goods production had increased in 1,3 times in general, in reliance on the unit of area - in 1,6times. The most effectively in the agrarian sector there had been used the labor, still the tempo of its payment considerably exceed the tempo of labor productivity increase in the agricultural enterprises.

Up till now the main sphere of work implementation in the village remains agriculture, that's why from the motivation of effective functioning of its basic branches depends the stable development of enterprises and welfare of the major part of rural population. Firstly it is connected with the implementation of the modern agrarian technics and new technologies. [9].

The investments revival of agriculture needs attraction into production of such volumes of investments which would provide the need in the necessary types of material- technical resources and create the conditions for the effective activity of the basic household formations: farmer households, and productive cooperatives. However, deep crises in the economics of Ukraine, especially in agriculture, which lasts during many years, had led to the destructive processes not only in the material and technical provision, and had also led to the fast reduction of the labor resources, decline of their age composition, degradation of land resources, decline of the agrarian production.

By estimate of the world organization on the food issues of Food and Agricultural Organization, Ukraine has the agrarian potential and possibilities for the considerable export of agrarian production expansion and overcoming the food crises. The investments revival of the agrarian economics needs mobilization of their own resources of financing, creation of the favorable conditions for involvements of the foreign capital, intensive growth of the long term favorable credit provision, strengthening the state investments support, and attraction the money of investors from other branches of economics, which are interested in the development of the agrarian production. [7].

By means of investigations, there had been established, that for activation of the investment activity, vitally important is the formation of the qualitatively new agrarian policy, directed on the increase of the investnent attractiveness of the agrarian production. Summing all up, and taking into consideration the state of the home investment market, we can group up the basic sources of the investment provision of the region's agrarian enterprises. (pic.1).

The essential relative share in the system of attraction investment resources into agriculture takes the real estate credit. In the contemporary conditions the bail and credit relations have to be equally right component parts in the modern agriculture, and the estate ones - with the crediting of not only the living buildings objects, but giving the long term credits to the farmer households and productive cooperatives on bail. 


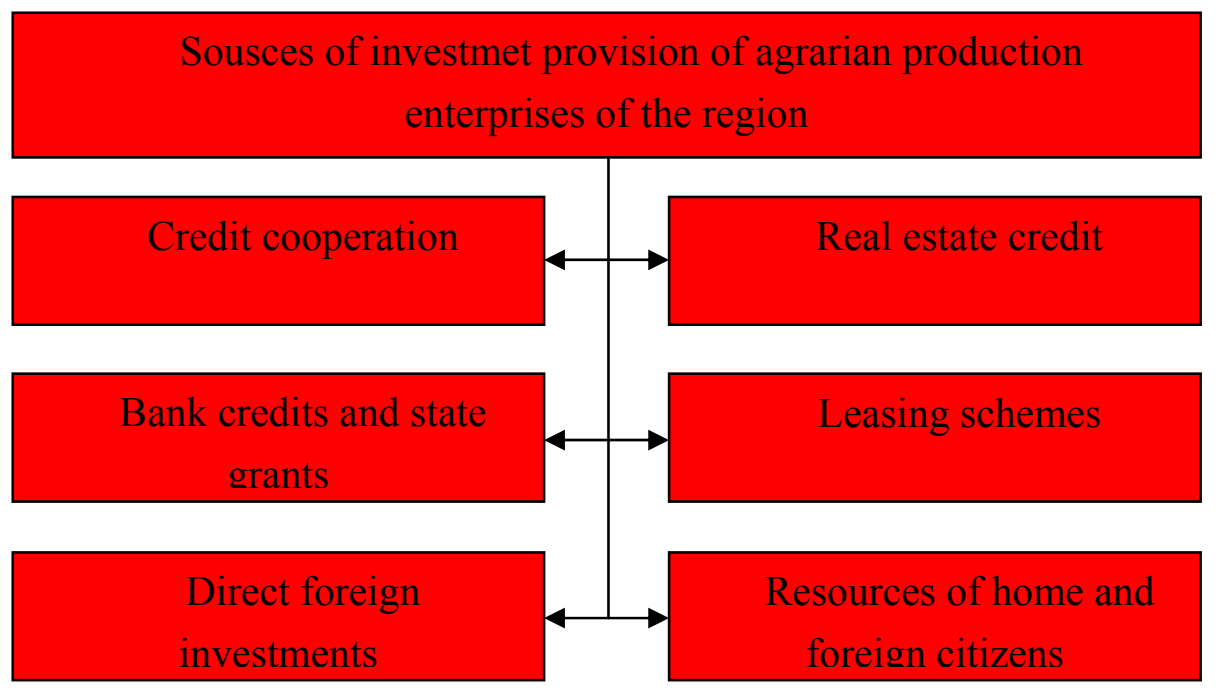

Pic. 1. Sources of investment provision of the agrarian enterprises

All the financing sources are divided into three groups: 1) own capital import; 2) own inner resources of the enterprises, which are under the control of the foreign investors (amortization fund) 3) external resources (loans, credits, new stocks and bonds issue, and so on) [10].k

On the contemporary stage, the institute of the real estate crediting in agriculture hadn't gained a corresponding development, while the possibilities of its use are real. Underinvestment and insufficient support of the agrarian sector on the side of the state should be compensated by the use of the outer budget sources of financing and while building the houses for the young generation of the village.

Because of the limitation of the investments costs the topical problem of agriculture becomes consolidation of all the possible financial resources for solving the strategic problems of Transcarpathia.

In the nearest perspective an important role in the investment provision of the agrarian sector is to be given to the leasing schemes. Leasing operations and their role in financing the investment activity of the agrarian enterprises (farmer households, and productive cooperatives) increase every year. Agrarian enterprises engrain the leasing operations for the reduction of the tax burden, for the management of the long term productive investments, for the simplification of the mutual settlement and commercial risks reduction. In any case, the use of the leasing operations in the investment activity of the enterprise has a strategic character12].

Organizing-economic mechanism of investments is an integral system, which includes three basic blocks of elements, which provide the search, attraction and mastering the investment resources (pic. 2). 


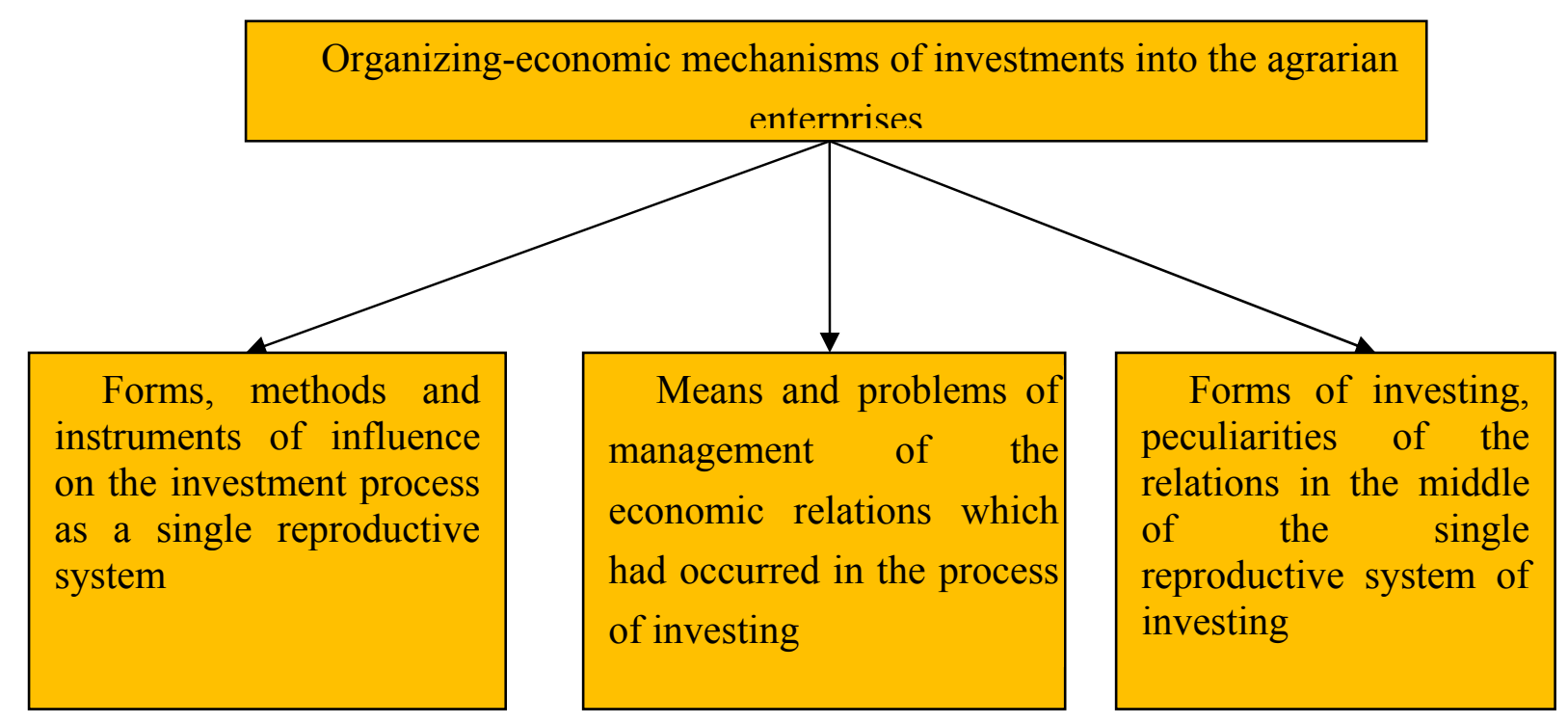

Pic. 2. Components of the organizing-economic mechanism of enterprise's investment

In agriculture of Transcarpathia, the volumes of investments into the basic capital are in the direct dependence from the volumes of the agrarian goods production.

With the further development of the market relations there considerably increased the objective dependence of the agrarian enterprises on the financial-credit system, as for the optimal functioning of the agrarian sector and providing its stable and positive reproduction process necessary is the rational correlation between their own and attracted funds. 


\section{Problems of investment provision of the agrarian enterprises}

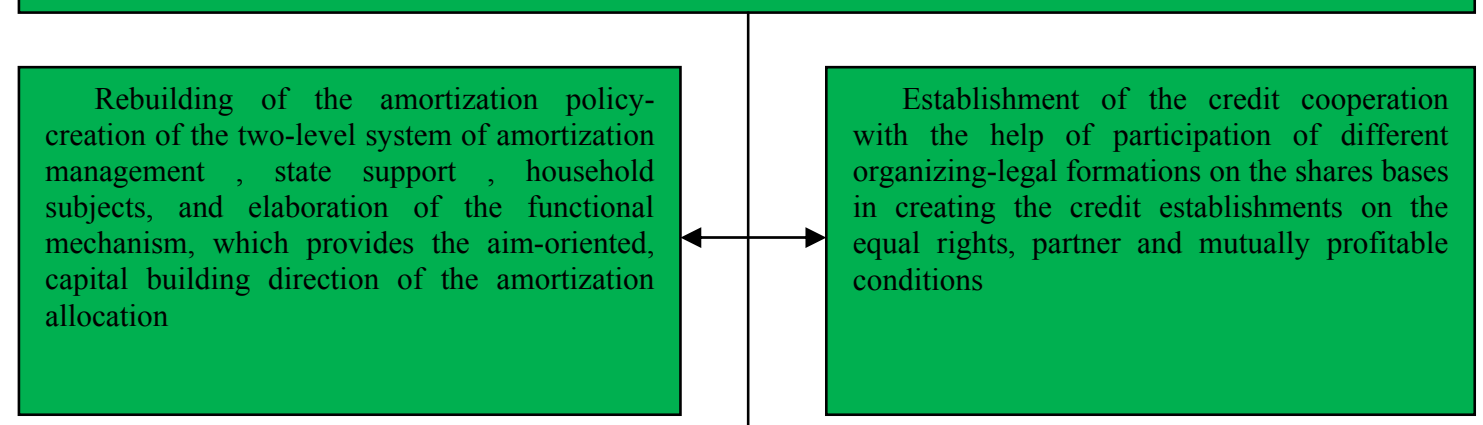

Creating the competitive environment in the sphere of banking activity and easing of credit for the rural investors. Alongside with the existing legislative basis of the State programme on forming the conditions and preconditions for the revival of credit cooperation which should foresee the degree of participation of banking structures in forming the investment resources, preferential taxation for cooperatives which direct most of their capitals on the productive aims and needs

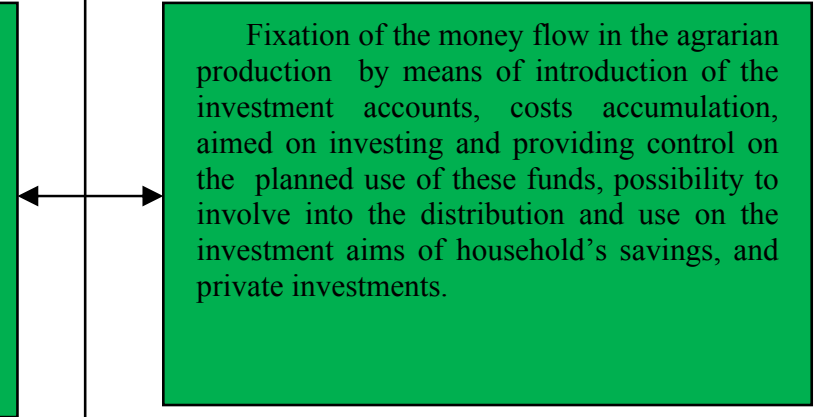

Spread of the real estate credits. Bails and credit relations should be equal component parts in the modern agriculture, and mortgage operations are connected with financing not only of the residential construction, but giving the long term loans to the farmer households as well

The use of the extra budgetary costs, the personal citizens' costs for the individual building, citizens 'funds, joined for houses building through the credit cooperatives, funds of the commercial banks, given as credits, funds of enterprises and organizations, which solve the housing problems of their coworkers.

Pic. 3. Problems of investment provision of the region's agrarian enterprises

The contemporary banking system of Ukraine proposes to the agrarian enterprises only three types of the short term bank credits: unrenewable credit line, term loan, and sometimes overdraft (term of such credits is $12-18$ month.). The majority of the home agrarian enterprises use the term loans up to one year, but they are not profitable for the producer.

(pic. 3). They are profitable for the banks, because the term of credit makes up 12 months and provides one productive cycle (this means, that agrarian enterprise cannot realize more than one cash cycle) and alongside with this, minimizes the risks of the debt loss. Besides, when giving the term loan, all the loan sum is being transferred by one tranche on the current account of the enterprise, and the return of the loan is being realized every month with the equal parts (for agricultural) and now in the agriculture of Transcarpathia there had been noticed a positive tendency for activation of the investment processes. In 2015 by means of all the financing sources there had been used $18 \mathrm{mln}$.hrn investments into the basic capital, which is in conversion to price component $32 \%$ less comparing with the previous year.

By means of investigations, there had been established, that in the structure of financing investment sources into agriculture, two thirds are the own funds of the goods producers and over $25 \%$ are the credits. Thus, the factual dynamics of investments into the basic capital of the branch, structural moves in the sources of financing investments into the branch witness on the necessity of the essential activation of investment processes, strengthening the role of the foreign investments and other attracted sources 
which is possible to achieve both - by the increase of the investment attractiveness of each enterprise, and by the improvement of the investment climate in the state.

The process of foreign investment as the factor of economic growth is the determinant one both on the state and regional levels. Such approach is preconditioned by the fact, that the foreign capital is one of the important sources of forming the financial- credit resources of the region, directions of stimulating the regional development and elimination of the local disproportions. [2].

Forming the preferable investment climate, involving the foreign capital and investment resources, and also increase of the national investments don't yet slow down the set of the negative factors, the most important from which are: inconsistent and imperfect state investment policy in the agrarian sector, in which the principles of residual appropriation on the needs of development of the budget sphere institution and indirect support of the projects of non-state investors, imperfect mechanisms and schemes of using the budget costs, non development of innovative infrastructure, excessive wear of the basic means and absence of the conditions not only for the extensive, but their simple reproduction, unfavorable conditions for the development of the small business in the village, low liquidity of investments, unsolved problem of the mortgage loans, insufficient financing of the measures as to the development of the roadway network in the rural area, imperfect mechanism of economic relations between the branches, which leads to the low capital profitability and investment attraction of separate agricultural branches of the region prevail.

Investors, who show interest to agriculture of Ukraine, have a rich work experience in other countries, which they can use. A chief factor of attraction for them is the soil, which in Ukraine wins according to the quality and demands twice or three times less fertilizers and technics per one hectare, comparing with the European soil. Using the approbated in Europe technologies in the given conditions will give a maximum and fast effect. [4].

Insufficient comparing to the world practice is a direct state investment support of agriculture, as only 2-3 \% of the general volume of investments in the branch makes up the costs of the state budget, while more than $14 \%$ of gross additional value of Transcarpathia is being produced here. Long term under financing had led to degradation of material-technical bases of the majority of agrarian enterprises.

The problem of investment provision of branch development is most serious on the agricultural enterprises. Alongside with this, the investment attraction differs according to the types of activity in the regions. [8].

The main strategic aims of the investment provision development of agriculture in the long term perspective taking into consideration the defined goal should be considered the following ones:

Forming the sources of financing for the full agricultural development needs provision in the investment resources;

Increase of the own investment possibilities of agricultural goods producers to the level that provides the optimal combination of the own and involved resources of investment financing;

Expansion of the volumes of financing the development of road facilities in the rural area as one of the key factors of increase the investment attraction of agriculture and its efficiency.

Assessments show, that in the region there are the sufficient possibilities to fully achieve the defined in the process of investigations points of the investment indicator already in 2015 (in comparative prices) which in 2010 made up 48, and in 2014- - $55 \%$. For this, it is necessary to raise the average yearly tempo of investment growth into the basic capital to $101,2 \%$ against $45,5 \%$ in average during 2006 2010 years.

Growth of the investment possibilities of the agrarian goods producers is characterized by such indicator of development as the increase of the part of the private sources of investments financing into the basic capital of agriculture in 2015 to the optimal level of - $65 \%$ against $51 \%$ in average during 2006 $-2010$. 


\section{Conclusions}

Reaching the mentioned above basic strategic aims of the investment provision of agricultural development in the long term perspective should be solved by means of:

Providing the forming of investment resources in agriculture according to the proportion, which is characterized by the correlation between the own personal and involved sources as 2:1;

Forming the mechanism of support of investments in farmer households and farmer cooperatives, creation the conditions for the prior development of animal farming, especially of the meat and milk cattle breeding at the expense of the state budget costs, credits and capital of the home and foreign private investors;

Providing stabilization and strengthening of the role of the credit mechanism in forming the sources of investment financing into agriculture;

Obstacle removal in the activity of the foreign investors in agriculture by means of adhering to the national interests;

Contributing to the process of creation on the deserted rural territories of the separated farms and their autonomous and independent resources provision.

So, we can confirm, that the development of agriculture in the strategic perspective needs a considerable improvement of its investment provision in the agrarian enterprises and farmer households; for the branch's development provision it is necessary for the prognoses volumes of investments into the basic capital in 2016 to make up 130, and in 2020- - $145 \mathrm{mln}$.hrn ; with the aim of realization the strategy of investment provision of agricultural development it is necessary to fulfill the measures as to the improvement of the state investment policy and mechanisms of its realization, to strengthen the financial support of investment processes activation, investment provision of the development of innovative infrastructure, roadway network in the rural area.

\section{Bibliography}

1. Agroindustrial complex of Ukraine: state, tendencies, and perspectives of development . Inform.analyt. coll. / under pub. P.T. Sabluk and others -K.: IAE UAAS, 2003. - ED.6. -764p.

2. Balyan A.V. Regional systems of foreign investment to Transcaarpathia. // Economics of AIC . 2004. - №7. - P.152-156.

3. Vovchak O.D. Investment./O.D.Vovchak.-Lviv:"Novyi svit-2000”, “007.-p.24.

4. Gavryliyk O.V., Lupenko Y.O. Investing into agrarian sector: identification and directions of obstacles removing// Economics of AIC. - 2009.- №5. - P. 63-68.

5. Hytman L.J., Jonk M.D. Investments bases. / Tr. From English-M.: bus., 1997. - 929p.

6. Mc Connel K.R., Brue S.L. Economics: principles, problems and politics/[trans. From Eng. 11-th ed.] - K.: Hagar-Demos, 1993. -785c.

7. Kvasha S.M. International Economic activity of AIC of Ukraine: State, strategy and tactics development / S.M. Kvasha. [monography]. - K.: CAC "NICHLAVA", 2000, - 252 p.

8. Kozhemiakina M.Y. State and directions of investment provision of agriculture // Agroinkom.-2007.№5-6.-P.42-46.

9. Malik M.Y. Motivation of productive activity in the agrarian sphere of economics. - K.: IAE YAAH, 1995. -177p.

10. Peresada A.A. Investment process in Ukraine. -K.:"Lybra ", 1996. -344p.

11. Statistic yearly annual of Transcarpathia over 2015. Statistics headquarters in Transcarpathia., under p.G.D.Grynnyk.- Uzhgorod:Consultant, 2016-543p.

12. Shkuratov O.I. Leasing operations and their role in financing the investment activity // Economics of AlK. -2012. № 11. - p. 65-69.

13. Markowitz,H. "Portfolio Selection". Journal of Finance 7, March 1952. 